\title{
REVIEW | Underground: The Subterranean Culture of DIY Punk Shows
}

Daniel Makagon

Portland, OR: Microcosm, 2015

ISBN 9781621065180 (PB)

\section{Sean Martin-Iverson \\ University of Western Australia}

sean.martin-iverson@uwa.edu.au

In Underground, Daniel Makagon provides a detailed ethnographic account of DIY punk performance culture in the United States, with a particular focus on the role of DIY house shows. Published by Microcosm, an independent publisher of books and zines specialising in DIY culture, the book has been produced as a accessible paperback volume that is both affordable and well-suited to the subject matter. Yet, while the book does not appear to be targeted primarily at an academic audience, it is also far from the kind of potted scene history or band biography most often associated with fannish works in this field. Rather, Makagon brings a distinctly sociological (or anthropological) sensibility to his account, exploring and drawing out the interplay of the spatial, cultural, economic and social practices that constitute the social world of DIY punk, albeit conveyed in a rather journalistic style. While this attempt at accessibility is not a complete success, most notably sacrificing some analytical precision and theoretical clarity, Underground nevertheless stands out as a substantial work offering a level of ethnographic "thickness" which is all too rarely found in writing on punk.

Organised conceptually rather than chronologically or geographically, Underground ranges across times and places to present a comparative and multisited ethnography of American DIY punk scenes. This is grounded in the author's own long-term engagement with the Chicago DIY scene, an "Explore Chicago" course on underground culture in the city where he teaches at DePaul University, as well as some dedicated fieldwork investigating scenes around the United 
States. This extensive participant observation is the foundation for Makagon's analysis, while also informing his use of interviews and underground media texts. Although some more extended case studies could have further benefited the work, Makagon successfully brings together a range of ethnographic examples to convey key commonalities and differences in the organisation of DIY shows and the various challenges faced by those involved. As a specifically American account, little attention is given to DIY punk as a global phenomenon or the ways in which global connections have shaped and reshaped American scenes. Those looking for a more global perspective can find it in Kevin Dunn's newly published Global Punk (2016), while Makagon presents a closer and more focused ethnographic study of American DIY punk shows.

Makagon's historical contextualisation of the scene is relatively brief but sufficient, addressing the development of the American hardcore punk underground in the 1980s and its eruption into the mainstream in the early 1990s, but his emphasis is on the ongoing "subterranean" culture of DIY punk in the United States as it continued through the 1990s and into the 2000s. He addresses the development of touring and booking networks, the establishment of DIY community spaces, and to a lesser extent the role of DIY labels, distributors and bands, but the primary focus of Underground is on the role of the DIY house show as a key institution of American DIY punk culture.

While presented primarily in the form of ethnographic description, Makagon does have an argument to make with Underground. His main point can be summed up as "space matters" (117), or, more specifically, that the cultural practices and social relations of DIY punk rely on the establishment of particular punk spaces organised according to DIY principles of autonomy and community, however transient, contested, and diverse these may be. For Makagon, at their best, DIY spaces are an external expression of the collective agency of DIY punk, as "material reflections of collectivist ideologies and identity politics" (206). Most central to his account are the punk houses used as DIY performing spaces, though he also addresses other types of venues, infoshops and organising centres, as well as the wider spatial dimensions of DIY scenes and touring networks. Makagon's discussion returns repeatedly to the ongoing struggle to establish and maintain DIY spaces, and to questions of sustainability and generational transition in DIY punk scenes. This includes a detailed examination of the ways in which spatial issues of location, layout, tenure and ownership shape the experience of DIY shows, and the ways in which differing urban environments, regulatory and policing regimes, economic strategies and scene histories have shaped DIY practices.

However, while the descriptive detail in Underground is organised in such a way as to present this argument about the spatial organisation of DIY sociality, the book could have been enhanced by a more explicit and developed discussion of the social theory concepts that inform the work, and of the critical and scholarly literature with which it is in dialogue. Makagon does refer in passing to various sociological and anthropological theorists, and to cultural critics familiar to many DIY activists, such as Thomas Frank and Stephen Duncombe, but Underground lacks such scholarly embellishments as citations, a bibliography, or an index. No doubt some of this is down to the limitations of an affordably priced small press publication, but there does appear to have been a deliberate decision to de- 
emphasise explicit engagement with social theory and the scholarly literature in order to make the book more accessible to a non-academic readership. Unfortunately, in practice this obscures much of Makagon's analysis, especially for those readers who are not familiar with ethnographic modes of social science writing. While the writing generally flows well, with rich descriptive detail assembled to convey an argument, at key points there are notable gaps where it seems as though important conceptual material has been removed. A bibliography would also have been useful, particularly for those readers who are not already familiar with the field.

That said, Underground remains an important work for punk studies, and is of wider interest to scholars in fields such as popular music studies, cultural sociology, urban anthropology and urban geography, and to many participants in DIY scenes. Its detailed exploration of the spatial practices and social organisation of DIY punk shows provides a useful complement to the emphasis on practices of media production within the existing scholarly literature on DIY punk. In its appeal to both scholars and practitioners, Makagon's book can be compared to Stephen Duncombe's study of underground zines Notes From Underground (1997), although Makagon's argument about the politics of underground culture is less explicitly developed. It can also be usefully read alongside Alan O'Connor's (2008) more analytical study of DIY record labels, to provide further insight into the affective experience of DIY sociality while addressing the important role of live music and DIY spaces. Although the book may come across as too scholarly for some fans, and not scholarly enough for some academics, punk scholars and DIY activists comfortable with the borderlands of academic, fan and social movement writing should find a great deal of value in Makagon's work.

\section{References}

Duncombe, S. 1997. Notes From Underground: Zines and the Politics of Alternative Culture. London: Verso.

Dunn, K. 2016. Global Punk: Resistance and Rebellion in Everyday Life. London: Bloomsbury.

O'Connor, A. 2008. Punk Record Labels and the Struggle for Autonomy. Lanham: Lexington. 